In the Sovereign Machine:

Sovereignty, Governmentality, Automaticity

Arthur Bradley

Lancaster University

\begin{abstract}
:
This essay explores a series of sovereign 'machines' - slaves, puppets, automata - in political theory from Benjamin to Agamben. It is now well-documented that the philosophical question of 'the machine' - of whether a complex system requires a human operator or whether it can function autonomously - is also a crucial political question that haunts every discussion of sovereignty from Hobbes onwards.

However, my wager in what follows is that this machine is not just a metaphor for a metaphysical situation - whether it be rationality (Hobbes), bureaucratization (Weber), neutralization (Schmitt), historicism (Benjamin) or governmentality (Foucault) - but a material phenomenon that carries transformative political promise and threat. To summarize the argument of this essay, I contend that 'sovereign machines' like slavery (Aristotle, Hegel, Kojève, Agamben), puppets, automata or clockwork (Descartes, Hobbes, Schmitt, Benjamin, Derrida), lens, optics and mirrors (Hobbes, Kantorowicz, Benjamin, Lacan, Foucault) and so on do not merely reflect but change our understanding of the causal relationship between sovereignty and governmentality, decision and norm, exception and rule. If the selfappointed task of the modern political theorist has so often been to obtain or regain sovereignty of, or over, the machine - to jam its gears - I seek to expose what the later Derrida calls the 'machine' of sovereignty itself. In conclusion, I argue that political theory's attempt to reveal or retroactively invent he sovereign person at the heart of the machine only ends up revealing the sovereign machine at the heart of the person. What - if anything - is really inside the machine of sovereignty?
\end{abstract}

Key words: Aristotle, Hobbes, Benjamin, Schmitt, Agamben, Sovereignty

Biographical Note: Arthur Bradley is Professor of Comparative Literature at Lancaster University. 
In the Sovereign Machine:

Sovereignty, Governmentality, Automaticity

It is well-known that an automaton once existed, which was so constructed that it could counter any move of a chess-player with a counter-move, and thereby assure itself of victory in the match. A puppet in Turkish attire, waterpipe in mouth, sat before the chessboard, which rested on a broad table. Through a system of mirrors, the illusion was created that this table was transparent from all sides. In truth, a hunchbacked dwarf who was a master chess-player sat inside, controlling the hands of the puppet with strings. One can envision a corresponding object to this apparatus in philosophy. The puppet called 'historical materialism' is always supposed to win. It can do this with no further ado against any opponent, so long as it employs the services of theology, which as everyone knows is small and ugly and must be kept out of sight (Benjamin 1968: 253)

In many ways, Walter Benjamin's First Thesis on the Philosophy of History (1941) remains every bit as impenetrable a machine as the chess-playing automaton (Schachtürke) it describes. It is difficult to embark on yet another reading of this famous allegory without feeling a little like the unwitting challenger who finds their every move anticipated and foiled by the remorseless mechanical Turk in front of him. After all, we all already know how this game will end: the machine will inevitably - indeed almost automatically - defeat any human opponent who is foolish enough to take it on. To re-play Benjamin's classic act of philosophical checkmate one more time: historical materialism can defeat any challenger with ease, he confidently declares, so long as 'it employs the services' of the hidden hunchbacked dwarf called 'theology' (Benjamin 1968: 254). Yet, as Rebecca Comay has observed, what makes this prophecy of historical materialism's almost automatic triumph in the chess game of history all the more mysterious is that it also seems to defeat the larger stratagem of the 'Theses' as a whole. For Benjamin, according to Comay's reading, this elliptical collection of fragments is an attempt to 'expose the ultimate illegitimacy of every victory' (Comay 1994: 260) by revealing the trail of destruction they leave in their wake: why, then, should we rejoice in any historical actor's claim to 'win all the time'? If we were to read the mechanical Turkish chessplayer as an avatar of social democracy instead, and the geometric squares of the chess board as the 'homogenous empty time' (Benjamin 1968: p. 254) that the latter occupies, then it becomes more tempting to interpret the First Thesis ironically as an attempt to critically unmask or demystify the pseudo-automaticity of this triumphalist ideology of linear historical progress - because, of course, the chessplaying Turk is really nothing but an elaborate puppet show and the chess game just a tawdry confidence trick. In the hidden recesses of every machine, there is a small, ugly human being who, Oz-like, is secretly pulling the strings all along. 


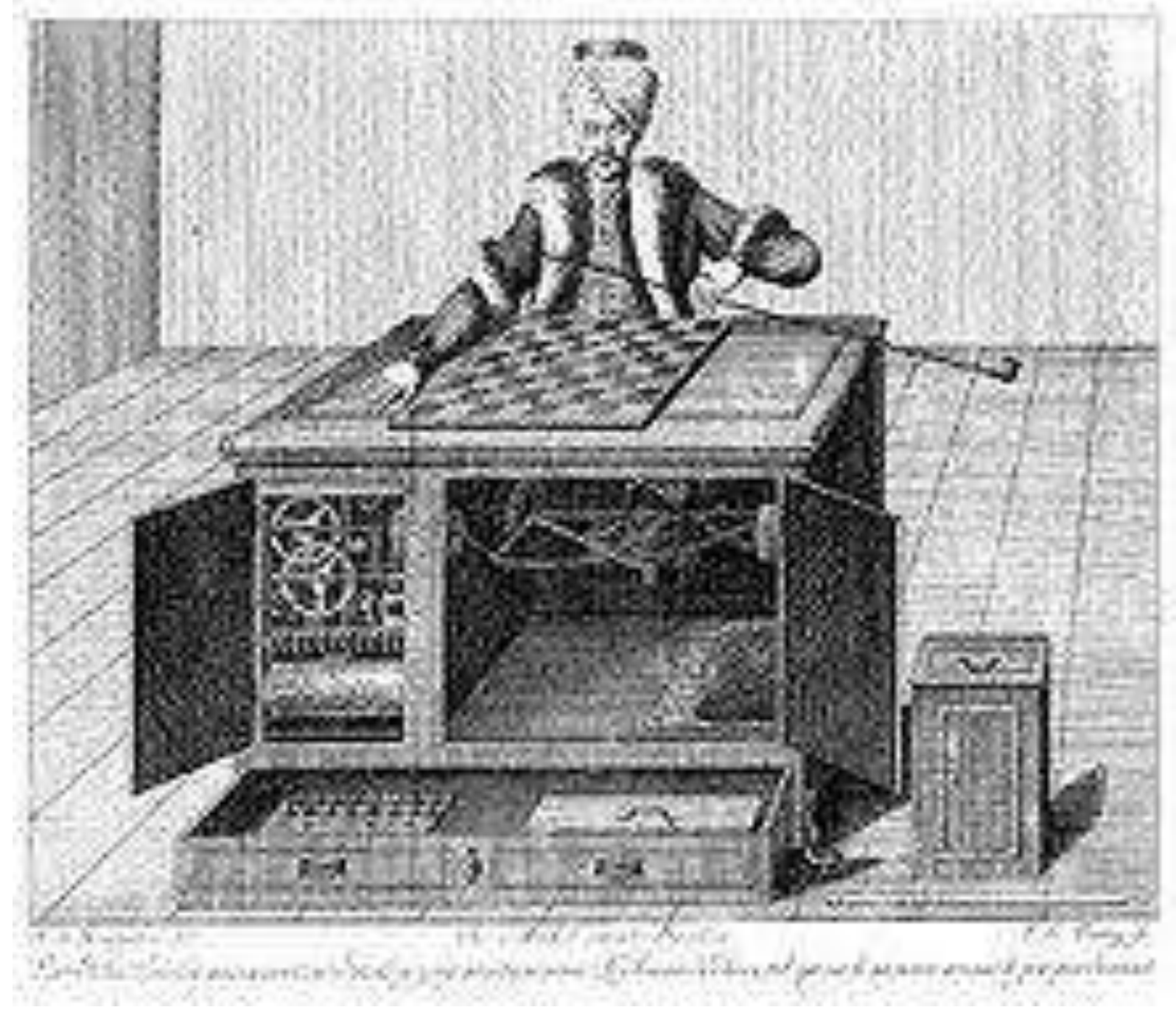

Figure 1: Engraving of the Mechanical Turk in Karl Gottlieb Windisch, Inanimate Reason: Or, A Circumstantial Account of that Astonishing Piece of Mechanism, De Kempelen's Chess-player, Now Exhibiting at No. 8, Savile-Row, BurlingtonGardens (1784). 
To open up Benjamin's machine and expose its inner workings to the critical light of day, though, I think we discover a mis-en-abyme which will recur serially in one form or another throughout this essay: the dwarf who pulls the strings of the puppet is not actually a human master at all but itself paradoxically a kind of 'puppet'. It is crucial to recognize here that, for all its insoluble mysteries, Benjamin's story of the chess-playing automaton seems to short-circuit the Schachtürke (Figure 1) in a way that problematizes any attempt to expose a hidden prime mover or cause at its heart. ${ }^{1}$ As many scholars have remarked, the First Thesis reverses the historical power relation between the puppet and the dwarf in Wolfgang van Klempen's original machine: the puppet of historical materialism now 'employs the services' of the dwarf of theology rather than the other way around. For Benjamin, in other words, this - apparently now living - puppet becomes the puppet-master of the dwarf: an instrumental or prosthetic 'cause' of its own efficient cause. ${ }^{2}$ If the dwarf and the puppet would initially seem to be opposed to one another - as the living versus the non-living, the organic versus the inorganic, user versus tool, cause versus effect and so on - Benjamin's allegory thus seems to re-inscribe both within a larger recursive machine or assemblage which brings to mind his mysterious prophecy at the end of One-Way Street about the advent of a new technological physis which exceeds the received oppositions between nature and culture and assumes an inorganic 'life' of its own: 'In technology', he writes, 'a physis is being organized through which mankind's contact with the cosmos takes a new and different form from that which it had in nations and families' (Benjamin 1996: 487). In the hidden interiority of Benjamin's machine, we do not find an Aristotelian efficient cause or a Cartesian homunculus so much as an infinite regress of puppet inside puppets, machines inside machines.

This essay proposes that Benjamin's First Thesis - a labyrinthine textual machine containing puppets and dwarves, masters and slaves, kings and queens - is only one of a series of 'machines' of sovereignty in modern political theory. It is my aim in what follows to try to set in motion a long overdue dialogue between two fields within modern critical thought that are historically inter-related but have, recently at least, diverged: theories of sovereignty, political theology, biopolitics et al (Schmitt, Benjamin, Agamben, Esposito) and theories of new media, technology and technogenesis (Benjamin, Heidegger, Simondon, Deleuze, Stiegler). 3 As many scholars have documented, the philosophical question of 'the machine' - of whether a complex system always requires a human operator or whether it can function autonomously - is also a crucial political question that haunts every discussion of sovereignty from at least Hobbes onwards: 'the sovereign...has been radically pushed aside', bemoans Carl Schmitt of the post-Deist universe, 'The machine now runs by itself' (Schmitt 1985: 48). However, my wager is that this self-moving or automatic machine is not just a metaphor for a prior metaphysical situation - whether it be rationality (Hobbes), bureaucratization (Weber), neutralization (Schmitt), historicism (Benjamin), governmentality (Foucault) or biopolitics (Agamben) - but a material phenomenon that carries transformative political promise and threat. To be sure, I am by no means the first critic to speak of a 'machine' of sovereignty - or of anthropology, political theology and so on infinitely - but what many previous discussions of the field arguably lack is a sense in which this is a quite literal as well as a philosophical proposition: what if technological objects, apparatuses and processes like slavery (Aristotle, Hegel, Kojève, Agamben), puppets, automata or clockwork (Descartes, Hobbes, Schmitt, Benjamin, Derrida), lens, optics and mirrors (Hobbes, Benjamin, Kantorowicz, Lacan, Foucault) and so on do not merely reflect 
but change our understanding of the causal relationship between sovereignty and governmentality, decision and norm, exception and rule and so on? For Aristotle in the Politics, recall, the slave is quite literally a species of flesh-and-blood tool [ktema ti empyschon] which, like the mythical tripods of Hephaestus which walked all by themselves up Mount Olympus, is seemingly capable of operating independently of its master (Aristotle 1984: 1253b 20-1254a 1). If the self-appointed task of the modern political theorist has so often been to obtain or regain sovereignty of the machine - to (in Benjamin's famous metaphors) stop the clock, jam the gears, apply the emergency brake on the runaway train of history and so on (Benjamin 2003: 402) - I want to expose what the later Derrida intriguingly calls the machine of sovereignty itself: 'Absolute sovereignty', he writes, 'is anything but natural; it is the product of a mechanical artificiality, a product of man, an artifact' (Derrida 2009: 29). In this essay, I argue that political theory's attempt to reveal the sovereign person at the heart of the machine - the master's power over the living tool called the slave (Aristotle); sovereign personalism over and against an autonomous selfregulating system of laws (Hobbes); historical materialist time over the empty time of social democratic progress (Benjamin) - ends up revealing the sovereign machine at the heart of the person. So, what - if anything - is really inside the machine of sovereignty?

\section{In the Body}

In Book 1 of the Politics, Aristotle claims that the slave is a living tool or animate instrument. To recall his famous (or notorious) argument here, the Greek philosopher seeks to defend the institution of slavery against those who were already insisting that it is contrary to nature - 'and that therefore it is unjust, for it is based on force' (Aristotle 1984: 1253b) - by arguing that the slave is a special kind of human being who is quite naturally the tool or property of its master:

Since, just as for the particular arts it would be necessary for the proper tools to be forthcoming if their work is to be accomplished, so also the manager of a household must have his tools, and of tools some are lifeless and others living (for example, for a helmsman the rudder is a lifeless tool and the look-out man a live tool-for an assistant in the arts belongs to the class of tools, so also an article of property is a tool for the purpose of life, and property generally is a collection of tools, and a slave is a live article of property (Aristotle 1984: $1253 b)$.

If there were actually such a thing as a self-moving or automatic tool - if shuttles could weave cloth and quills play harps - then, Aristotle claims, 'master-craftsmen would have no need of assistants and masters no need of slaves' (Aristotle 1984: 1253b). In the absence of such mythical machines that are able to run all by themselves, though, it seems the master must continue to use this 'living tool'.4 What, though, might be said to be 'inside' the machine called the slave?

To open up the original political or sovereign machine called slavery, Giorgio Agamben's The Use of Bodies (2015) seeks to recuperate what he calls a liberatory 'nucleus' within Aristotle's theory of natural slavery from both its anachronistic and moralizing philosophical reception history and the incontestably real and brutal history of the institution of slavery itself (Agamben 2016: 10). It is now commonplace 
to read Aristotle's naturalist account of slavery as little more than an ideological naturalization of human exploitation to meet the growing demand of economic production in Ancient Greece. After all, it is surely too much of a coincidence that a society with a cheap and abundant supply of human labour, but a comparatively primitive technological base or infrastructure, should spontaneously come to the conclusion that slavery is 'natural'. Yet, Agamben seeks to turn this ideological argument on its head by claiming that what is at stake in natural slavery is the exact opposite of the reduction of a human being to a sub-human animal, object or tool. For Agamben, Aristotle's theory of the slave is not an act of dehumanization but actually a microcosm for the event of anthropogenesis itself: what we confront in the slave is nothing less than the 'becoming fully human of the living being' (Agamben 2016: 78). If Aristotle's theory of the master-slave relation would seem at face value to imply a simple power relation of user and tool - of cause and effect, subject and object - Agamben finds within the Aristotelian category of 'use' what he famously calls a zone of indifference [zona di indifferenza] between these polarities which properly belongs to no-one or nothing. In this expanded sense, the slave becomes the last privileged figure for what Agamben famously calls a 'form of life' in which, rather than being biopolitically opposed, isolated and captured, zo $\bar{e}$ and bios, life and form, essence and existence irreducibly coincide with one another.

For Agamben, what is most crucial in Aristotle's theory of slavery is the Greek philosopher's obscure claim that the slave is a special kind of human being whose work is 'the use of the body [oson esti ergon he tou somatos chresis]' (Aristotle 1984: $1254 \mathrm{~b} 17-20$ ). Its work or labour belongs to the realm of practical activity (praxis) rather than production (poiesis). According to the Greek philosopher, slavery is thus a work that is also curiously 'workless' (argos) - because it never produces some end or goal (telos) external to itself in the form of an object or product. For Aristotle, a slave is thus less analogous to, say, a carpenter who makes beds than to something like a bed itself, because both slave and bed are items of 'equipment' (ktema) which are used as parts of the totality of objects that make up practical everyday life:

Now 'equipment' has the same meaning as 'part' [morion, 'piece', what belongs to an ensemble']; for the part is not only a part of something else [allou] but totally belongs to it...The same can be said for equipment (Aristotle 1984: 1254a 1-17).

If the slave is 'equipment' - a part in a functional ensemble or whole rather than a thing in itself - then Aristotle is able to conclude that he is not only slave of the master but, in a sense that goes far beyond mere analogy, 'totally [part] of him' (Aristotle 1984: 1254a 13). This claim is not only to be understood instrumentally or juridically - in the sense that the slave is the legal property of the master and he can do with him what he wants - but even organically: what we call a slave is an 'organ [organon]' in the master's own body and, in using the body of the slave, the master is using his own body (Agamben 2016: 13-14). In the Aristotelian category of the 'use of the body', Agamben thus claims to discover a point of originary indifference or indeterminacy between one's own body and that of another: master and slave, subject and object, user and tool are folded back into one another: '[S]lavery defines a quite singular dimension of the human being (that the slave is a human being is...beyond any doubt), which the syntagma "use of the body" seeks to name' (Agamben 2016: 10). 
In his 'archaeology of slavery', then, Agamben seeks to discover within the masterslave relation itself the 'archaic nucleus' of 'another human activity and another relation within the living body' (Agamben 2016: 78): what is traditionally described as a crude power relation of subject and object, user and tool, is thus daringly edescribed as a state of freedom from power relations. It is only by returning to this archaic 'use of bodies' within the master-slave relation - rather than peacefully or violently exiting that relation in a gesture of Hegelian-Marxian overcoming - that, apparently, modern humanity can free itself from the liberal capitalist machine that runs all by itself. As Agamben observes, 'human beings have estranged themselves from the animal and from the organic in order to draw nearer to the instrument and to the inorganic to the point of almost identifying with it (the human-machine)' (Agamben 2016: 79).5 Yet, all this begs the question of what exactly such a positive theory of slavery as the free use of bodies might look like in actuality, given that it seems to exist almost nowhere in the theory or praxis of slavery, and his answer is revealing. For Agamben, Aristotle's 'use of the body' seems to find its privileged site in the - apparently wholly natural, normal and legal - sexual relationship between master and slave where, in using his own body, the master also uses the body of the slave:

If one dreams of masturbating with one's hands, it means that one will have sexual relations with a male or female slave, insofar as the hands that approach the genitals are serviceable [hyperetikas] (Artemidorus, Interpretation of Dreams, quoted in Agamben 2016: 16). ${ }^{6}$

If the slave is quite literally a part of the master's own body, who exists only in order to serve him, then it is little wonder that Artemidorus is able to reveal that autoeroticism and hetero-eroticism - masturbation and sexual intercourse, sex with one's own body and sex with another body - enter into a zone of indifference. In sexuality, the slave could be said to interrupt the pure ipseity of the master's subjectivity: subject and object, user and tool, inside and outside exist in a relation of pure immanence.

What, then, might be said to be inside the sovereign machine called the Aristotelian slave? To jump to Agamben's broader philosophical conclusion in Use of Bodies, the master and slave's reciprocal use of each other's bodies ultimately reveals a modal ontology in which human being or 'essence' is nothing outside, or extrinsic to, its own concrete 'uses' or modes of existence in time and space: 'Human being and world are, in use, in a relationship of absolute and reciprocal immanence; in the using of something, it is the very being of the one using that is first of all at stake' (Agamben 2016: 30). It is no longer possible to speak of a pre-existing human interiority - a subject - which then 'uses' some object exterior to itself as its tool, because that interiority is itself constituted in the very gesture of being exteriorized. As Agamben reminds us, Spinoza had already observed the Ladino verb pasearse might idiomatically mean 'to take a walk' but it literally means "to walk-oneself': we constitute ourselves as selves in the act of walking, talking, kissing and so on. For Agamben, in other words, we might say that what is most 'inside' the living tool called the slave - indeed inside every human body - is thus not some Aristotelian soul or Cartesian homunculus but precisely its 'becoming-outside' in the act of use:

Here the sphere of action of the self on the self corresponds to the ontology of immanence, to the movement of autoconstitution and of autopresentation in 
which not only is it not possible to distinguish between agent and patient, but also subject and object, constituent and constituted, are indeterminated (Agamben 2016: 29).

If we want a particularly graphic example of this relation of 'absolute and reciprocal immanence' between interiority and exteriority, we need only return to Artemidorus's curious prediction in the Interpretation of Dreams: a master who dreams of masturbating with his hand will go on to have sexual relations with his slave. This can only really be because, in a sense, he has already had sex with his slave in the act of masturbating with his hand - the master's hand is itself a 'slave', serviceable equipment, another 'instrument for instruments [organon pro organon]' according to Aristotle's famous definition in De Anima (432a 2). In the sovereign interiority of the master's own body, we find the living tool called the slave.

\section{Behind the Curtain}

In Abraham Bosse's famous frontispiece to the original edition of Thomas Hobbes' Leviathan (1651), an image which was apparently designed according to the author's own specifications, we find one obscure embellishment: a curtain (Figure 2). To recall this curious detail, Hobbes' proper name - Thomas Hobbes of Malmesbury and the book's full title - Leviathan or The Matter, Forme and Power of a Common Wealth Ecclesiasticall and Civil - are emblazoned upon a drawn embroidered curtain beneath the famous figure of the vast 'mortal God'. It is surprising that, despite the large body of literature now devoted to decoding the meaning of Bosse's frontispiece, this specific adornment seems to have attracted little or no attention. According to Carl Schmitt, who offers one of the only commentaries upon it in a 1947 entry in his Glossarium, the mysterious curtain signifies 'the façade of dominion (Herrschaft) in front of power (Macht)' (Schmitt 1991: 39-40) whereas the modern art historian Horst Bredekamp compares it to 'the pattern of the velum that concealed the tabernacle of the Old Testament as an arcanum' (Bredekamp 1991: 32). If Hobbes' curtain is generally passed over in silence, it is perhaps because its presence appears to obscure or even eclipse the new political economy of spectacle upon which the power of the Leviathan resides. For Hobbes scholars, after all, what is most remarkable about Bosse's frontispiece is the transparency of the 'mortal God' whose vast body is visibly, literally and figuratively composed of the multitude who come together to make up his sovereignty. What arcanum imperii, then, could possibly lie behind Leviathan's curtain if everything has supposedly been revealed?

To open up Hobbes' own early modern sovereign machine, I want to begin by placing his political revolution in the context of the scientific and technological revolutions of the $17^{\text {th }}$ century which were first mapped by Steven Shapin and Simon Shaffer in their classic Leviathan and the Air Pump (1985). It is intriguing, for instance, that the curtain on the book's frontispiece is placed directly in front of the lower half of the great Leviathan's artificial body - almost as if it were designed to conceal the hand of a (Benjaminian?) puppeteer. As many historians have documented, Hobbes' revolutionary new political philosophy runs in tandem with a revolutionary new philosophical anthropology: Descartes had already compared the human body to a spring-operated clockwork mechanism like a clock or watch little more than a decade before Leviathan in his Meditations.7 For Hobbes, this new philosophical question can an artificial body run all by itself independently of any animating soul? - is 


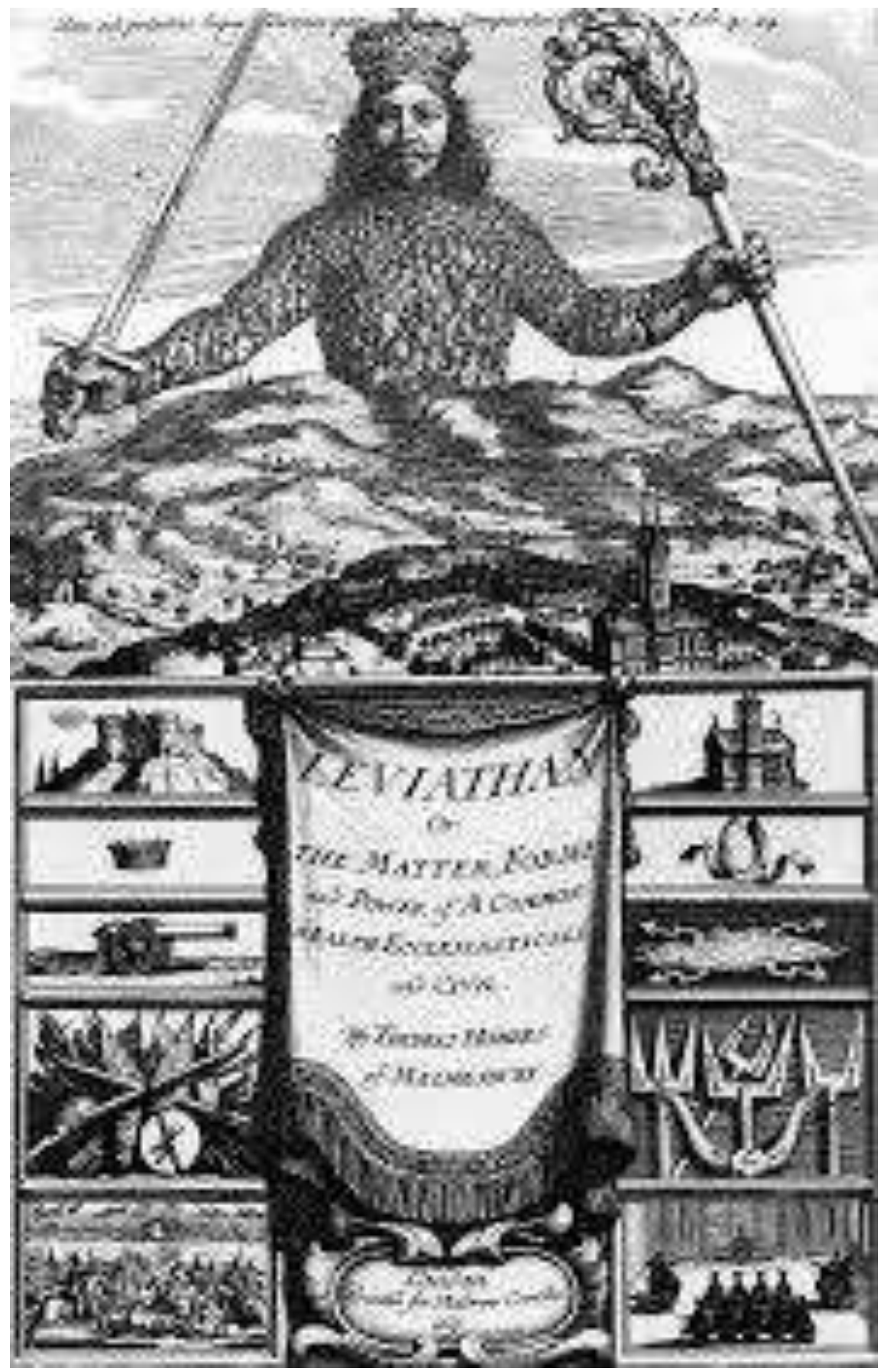

Figure 2: Abraham Bosse, Frontispiece to Thomas Hobbes, Leviathan (1651) 
transformed into the classic modern political question of whether an artificial body politic can function entirely autonomously of its animating sovereign homunculus. In the celebrated opening to Leviathan, the English political philosopher asks: 'For seeing life is but a motion of Limbs, the beginning whereof is in some principall part within; why may we not say, that all Engines that move themselves by springs and wheeles as doth a watch) have an artificiall life?' (Hobbes 1991: 1).

For the early Carl Schmitt of Political Theology (1922), Hobbes is the last great hero of the philosophy of sovereign personalism or decisionism which insists upon the presence of a concrete sovereign person who lies 'behind the curtain', so to speak, of the great artificial man of the state: 'The classical representative of the decisionist type', he famously writes, 'is Thomas Hobbes' (Schmitt 1985: 33). It is revealing, though, that the German philosopher already detects even here a tension between Hobbes' political theory 'which remained personalistic and postulated an ultimate deciding instance', on the one hand, and his 'natural-scientific approach' which 'reduced the individual to an atom', on the other (Schmitt 1985: 225). As he goes on to argue in his later Leviathan in the State Theory of Thomas Hobbes (1938), this structural tension between Hobbes' political personalism and his philosophical materialism ultimately explains why such a 'classic representative of the decisionist type' has instead become renowned as the progenitor of modern liberalism and the very neutralization and de-politicization of the state he would have abhorred. To briefly recall Schmitt's somewhat esoteric argument in this later text, Hobbes' tragic fate can apparently be traced all the way back to his decision to employ the Biblical figure of the Leviathan - the mythic sea beast - to symbolize his ideal Commonwealth. However, in spite of exploiting the power of myth in the construction of a political state, Schmitt alleges that Hobbes fatally chose the wrong symbol upon which to build a unified religious and political Commonwealth because he failed to recognize that its mythic power served to divide more than unify: what Hobbes intended to be the awesome signifier of absolute and incontestable state power in his time instead became 'the symbol of a monstrosity' (Schmitt 2008: 81) which only succeeded in uniting its enemies against it. If the Jews of the Old Testament feared the sea monster as a symbol of hostile pagan forces, Schmitt (whose anti-liberalism and anti-Semitism begin to merge at this point) argues that modern 'liberal Jews' like Spinoza and Mendelssohn were equally suspicious of the absolute power of the Hobbesian state: Spinoza exploits Hobbes' modest concession that the religious subject possesses freedom of conscience to make good the classic liberal claim that the individual is the authentic source of public sovereignty. In this way, Hobbes' mighty ‘Artificiall Man' was gradually emptied of all authority to the point where it became little more than a massive Weberian state bureaucracy administering for private men (Schmitt 2008: 53-64) - an empty puppet controlled by myriad liberal dwarves.

In Schmitt's notorious diagnosis, then, Hobbes's totalist theory of the state suffered from a fatal design flaw or structural weakness - a 'barely visible crack in the theoretical justification of the sovereign state' (Schmitt 2008: 57) - that liberal Judaism could prize open in order to break the Leviathan in two. It is less widely recognized, though, that Schmitt proposes another, very different, answer to the question of why the Leviathan fails in his book which, intriguingly, prefers to internalize the historical division between Hobbes' sovereign absolutism and Spinoza's liberal individualism within the mechanical body of the Leviathan itself. According to Schmitt - whose own text was written to mark the $300^{\text {th }}$ anniversary of 
the publication of Descartes' Meditations - Hobbes' theory of the state is not merely based on the ancient political mythopoeia of the Biblical Leviathan, but on this radically new scientific philosophical anthropology: 'Hobbes transfers - and that seems to me the gist of his philosophy of state - the Cartesian concept of man as a mechanism with a soul onto the "huge man", the state, made by him into a machine animated by the sovereign representative person' (Schmitt 2008: 32). To read it in this context, Hobbes' philosophy is less a political theological mythography than a species of political Cartesianism which projects Descartes' dualist theory of man where the human is composed of mechanical matter and immaterial mind - into a dualist theory of the state as composed of a mechanical body and sovereign personalist 'soul'. Yet, Schmitt argues, Hobbes arguably outstrips even Descartes, because in the end his state is not dualist at all, but radically monist. If Descartes is very clear that it is only the body of man that can be compared to a machine, Hobbes chooses to extend the mechanism to swallow up the soul as well: Schmitt correctly contends that the 'sovereign-representative person' at the center of the Hobbesian state machine is not to be confused with some metaphysical sovereign person like God or a Divine Right King because his sovereignty is the product of a purely formal and juridical process of authorization and representation. This is why Schmitt can conclude that, far from arresting the liberal mechanization of the state, Hobbes' theory of the sovereign person accelerates and completes it, because it rendered the state in its entirety a homo artificialis: Leviathan is 'the first product of the age of technology', the German philosopher argues, 'the first modern mechanism in a grand style, as a machine machinarum' (Schmitt 2008: 34). In a final turn of the historical wheel, Hobbes' original politicization of Descartes' philosophical anthropology which turned the latter's theory of man as a mechanism with a soul into his own theory of the state as a pure machine in both body and soul - was itself later reanthropologized by the French materialist philosopher Julien de la Mettrie when he devised his theory of man as a soulless 'homme-machine':

After the body and soul of the huge man became a machine, the transfer back became possible, and even the little man could become a homme-machine. The mechanization of the concept of the state thus completed the mechanization of the anthropological image of man (Schmitt 2008: 37; see also Mettrie 1912).

Who or what, then, lies behind the 'curtain' of Hobbes' sovereign machine? It is striking that Schmitt's tragic or fatalist narrative of the decline of sovereign personalism and the rise of liberal neutralization seems to run contrary to the principle of the philosophy of mechanism: any concept of a 'universal mechanism' necessarily describes a closed, determined and predictable universe, that would surely be impervious to the kind of tragic falls, accidents or deviations described by the German political theorist. Accordingly, Schmitt may have been more right than he knew to describe the Leviathan as a 'machine machinarum' - a meta-machine or machine of machines - because it seems to possess a technogenetic power of its own. To demystify what she sees as the illiberal fatalism at work in our contemporary obsession with Schmittean political theology, Victoria Kahn has argued in her recent book The Future of Illusion (2014) that we must return to Vico and Hobbes's own famous concept of 'poiesis' or making and insist upon the man-made or artefactual roots of the state: 'we can know only what we have made or constructed ourselves: verum et factum conventuntur (truth and fact - in the sense of that which is done or 
made - are interchangeable)' (Kahn 2014: 6). Yet, in spite of Kahn's claim that that Hobbes himself is behind his own curtain - that the state is a man-made artefact that remains under the control of its maker at all times - it is possible to argue that there is another, very modern, poietic principle at work in Schmitt's fatalist reading of Leviathan. For Schmitt, what is tragic about the fate of Hobbes's sovereign machine is not simply that it is badly-made or ill-used but more precisely that it escapes the control of its maker and begins to machinically re-make itself outside and against his animating intention: 'The spiritual weapons forged by Hobbes did not serve his cause' (Schmitt 2008: 85). If Schmitt is right that Hobbes' philosophy is unable to reconcile the competing demands of mythic sovereign personalism and representational state systems, if the sovereign representative person turns out to be not the immaterial soul of that machine but merely the final cog in the engine, if the 'Artificiall Man' ends up unwittingly bringing into being the very neutral liberal and technological state apparatus it sought to arrest and delay, then the fate of the Leviathan arguably symptomizes, not poiesis, but something closer to what Maturana and Valera will famously call 'autopoiesis': we can never know what we have made or constructed ourselves because what we have made re-makes itself in ways that continually escape and resist our knowing (Maturana and Valera 1980). In other words, what lies behind Hobbes' curtain is not a human sovereign but a machine that has succeeded in obtaining a technological sovereignty of its own.

\section{In the Wings}

In this essay, I have argued that modern political theory describes what (in both sense of the genitive) we might call a 'machine of sovereignty'. To reiterate my central hypothesis: what begins as an attempt to reveal - or retroactively invent human or personal sovereignty over a vast series of political machines which appear to operate quite independently of their users ends up exposing a more profoundly autonomous assemblage which incorporates human and machine, user and tool, subject and object alike. It would be possible, of course, to pursue the trajectory of these sovereign machines far beyond Aristotle, Hobbes, Benjamin, Schmitt and Agamben. As is now well-documented, for instance, Hobbes' theory of the state owes a great deal to the new science of optics and this politics of special visual effects mirrors, lenses etc. - endures across a range of signatures, texts and sites from Foucault's famous account of the mis-en-abyme of sovereignty at the heart of Velasquez's Las Meninas (Foucault 1973) to Lacan's psychoanalytic reading of anamorphosis in Holbein's The Ambassadors (Lacan 1998). For me, though, what is principally at stake in the question of the sovereign machine is a re-conceptualization of the historical, political and conceptual 'fates' of sovereignty itself in modernity. If the dwarf is already a puppet, if the master is already a species of slave, if the sovereign is himself a kind of homme-machine, then (and here is the speculation with which I would like to conclude), the relationship between sovereignty and its various historico-political prostheses - politics, democracy, liberalism, bureaucracy, governmentality, economy, biopolitics and so on serially - will perhaps also need to be radically re-thought: the machine was always already running all by itself inside the sovereign person. In this scenario, what Foucault, Agamben et al. call 'governmentality', for example, is less a contingency which (whether tragically, culpably or positively) befalls sovereignty from without at some moment in history than the quasi-automatic outworking of a kind of originary or immanent governmentalization at the heart of sovereignty itself. What if, in an inversion of 
Louis Adolphe Thiers famous formula, the King governs but does not reign (le roi gouverne mais il ne règne pas)?

To bring down the curtain on this discussion, though, I want to go back to where we started and consider one final Benjaminian sovereign machine: the angel. It will be remembered that the baroque fable of the chess-playing automaton who wins all the time is accompanied by another, equally mysterious but far more pessimistic, allegory for the fate of historical materialism in the 'Theses on the Philosophy of History'. For Benjamin, the Angel of History famously described in Thesis Nine is itself arguably another 'puppet' who is propelled by superior inhuman forces beyond its control to an equally inevitable -indeed almost automatic - defeat:

This is how one pictures the angel of history. His face is turned toward the past. Where we perceive a chain of events, he sees one single catastrophe that keeps piling ruin upon ruin and hurls it in front of his feet. The angel would like to stay, awaken the dead, and make whole what has been smashed. But a storm is blowing from Paradise; it has got caught in his wings with such violence that the angel can no longer close them. The storm irresistibly propels him into the future to which his back is turned, while the pile of debris before him grows skyward. This storm is what we call progress (Benjamin 1968: 257-8).

If there are obviously many plausible sources for this celebrated thought experiment - from Paul Klee's own Angelus Novus to Judaeo-Christian theology - it should also be remembered that Benjamin's image of an angel being overtaken by historical modernity has a precise machinic origin in his own thought: the invention of the locomotive steam engine in the early $19^{\text {th }}$ century. In his 1937 essay 'Eduard Fuch: Collector and Historian', recall, Benjamin satirizes an obscure $19^{\text {th }}$ century aesthetic cult of technological progress which responded to rising industrialization by constructing a peculiar angelology of the machine: 'The disciples of Saint-Simon started the ball rolling with their industrial poetry; then came the realism of a Du Camp who saw the locomotive as the saint of the future; and a Ludwig Pfau brought up the rear: "It is quite unnecessary to become an angel", he wrote, "since the locomotive is worth more than the finest pair of wings" (Benjamin 1975: 34).

Why, then, does Benjamin's Ninth Thesis conclude that, contra Ludwig Pfau, it is necessary to 'become an angel' - if only by adopting the quasi-angelic perspective upon history of the historical materialist? Is it yet another dramatization of the pseudo-automaticity of every claim to historical progress or victory which seeks to expose the trail of destruction the latter leaves in its triumphal wake? Or might it stage a more complex (or at least less complacently sentimental) tableau in which machinic automaticity is something more than a mere optical illusion or special effect to be unmasked by our critical bonne conscience? To be sure, Benjamin's thought experiment can all too easily be read as one more attempt to expose the wizened theological dwarf concealed inside the apparent locomotive of historical progress: this new Angel of History is clearly no 'saint of the future'; it looks backwards not forwards, and, most importantly, it is propelled onwards into the future against its own will: 'a storm is blowing from Paradise; it has got caught in his wings with such violence that the angel can no longer close them'. Yet, once again, the dwarf may turn out to be just another puppet because Benjamin's sovereign messenger warning against the pseudo-automaticity of history is itself a species of 
governmental 'machine'. For Agamben, whose genealogy of governmentality The Kingdom and the Glory (2007) devotes an entire chapter to the baroque Scholastic theological discipline of angelology, the angel is less the avatar of God's absolute sovereignty than the figure of the autonomous government of the world par excellence:

What is decisive [...] is that, long before the terminology of civil administration and government was developed and fixed, it was already firmly constituted in angelology. Not only the concept of hierarchy but also that of ministry and mission are [...] first systematized in a highly articulated way precisely in relation to angelic activities (Agamben 2011: 158).

If angels are a special kind of administrative being created by God purely in order to govern the world autonomously on His behalf, as Agamben alleges, then it becomes possible to read Benjamin's own Angel of History back against itself as yet another machine inside a machine: what is being described here is perhaps a kind of virtual or originary becoming-government at the heart of sovereignty itself. This winged avatar of sovereign weakness or impotence - who is seemingly powerless to intervene in the face of worldly catastrophe no matter how much he would like to do so - thus might perversely be re-imagined as a figure of modern laissez-faire governmentality whose job is precisely to withdraw to the wings, to let things take their own course according to their own nature and to do nothing more than bureaucratically keep a record of the profits and losses. In Benjamin's parable of the Angel of History - vainly seeking to apply the emergency brake to the runaway train of history - we find another governmental locomotive running all by itself.

\section{WORKS CITED}

Agamben, G. (2011) The Kingdom and the Glory: For a Theological Genealogy of Economy and Government (Homo Sacer II, 2, trans. by Lorenzo Chiesa, Stanford University Press, Stanford, CA.

Agamben, G. (2016) The Use of Bodies: Homo Sacer IV, 2, trans. by Adam Kotsko. Stanford University Press, Stanford, CA.

Aristotle (1984) Politics in The Complete Works of Aristotle: The Revised Oxford Translation ed. by Jonathan Barnes, Princeton University Press, Princeton, NJ. Balfour, I. (1991) 'Reversal, Quotation (Benjamin's History)', Modern Language Notes 106, pp. 622-47.

Benjamin, W. (1975) 'Eduard Fuchs: Collector and Historian', trans. by Knut Tarnowski, New German Critique No. 5, pp. 27-58.

Benjamin, W. (1968) Theses on the Philosophy of History, in Illuminations, trans. by H. Zohn, Schocken, New York.

Benjamin, W. (1996) One Way Street in Selected Writings, Volume 1: 1913-1926 trans. by Marcus Bullock and Howard W. Jennings, the Belknap Press, Cambridge, MA., pp. 444-88.

Benjamin, W. (2002) 'Paralipomena to "On the Concept of History"' (1940) in

Selected Writings, Volume 4: 1938-194O, ed. H. Eiland and M. W. Jennings, Harvard University Press, Cambridge, MA., p. 402.

Bradley, A. (2011) Originary Technicity: The Theory of Technology from Marx to Derrida, Palgrave, London. 
Bredekamp, H. (2007) ‘Thomas Hobbes’s Visual Strategies' in Cambridge Companion to Hobbes's Leviathan ed. Patricia Springborg, Cambridge University Press, Cambridge, pp. 29-60.

Comay R. (1994) 'Benjamin's Endgame' in Walter Benjamin's Philosophy:

Experience and Destruction ed. by Andrew Benjamin and Peter Osborne, Routledge, London, pp. 251-90.

Derrida, J. (2009) The Beast and the Sovereign: Volume 1, trans. by Geoffrey Bennington, The Seminars of Jacques Derrida, University of Chicago Press, Chicago, IL.

Descartes, R. (1986) Meditations on First Philosophy trans. by John Cottingham Cambridge University Press, Cambridge.

Esposito, R. (2015) Two: The Machine of Political Theology and the Place of Thought trans. by Zakiya Hanafi, Fordham University Press, Fordham, NY. Foucault, M. (1973) The Order of Things, trans. by Alan Sheridan, Vintage, New York.

Hobbes T. (1991) Leviathan or The Matter, Forme and Power of a Common Wealth Ecclesiasticall and Civil ed. by Richard Tuck, Cambridge Texts in the History of Political Thought, Cambridge University Press, Cambridge.

Kahn, V. (2014) The Future of Illusion: Political Theology and Early Modern Texts, University of Chicago Press, Chicago, IL.

Lacan, J. (1998) The Seminar Book XI: The Four Fundamental Concepts of

Psychoanalysis, ed. by Jacques-Alain Miller, trans. by Alan Sheridan, W.W. Norton \& Company, New York.

Maturana H.R. and Valera, F.J. (1980) Autopoiesis and Cognition: The Realisation of the Living, D. Reidel, Dordrecht.

Mettrie, de la J. (1912) Man a Machine trans. by G.C. Bussey, Open Court, Chicago, IL.

Rabinbach, A. (1992) The Human Motor: Energy, Fatigue, and the Origins of Modernity, University of California Press, Berkeley, CA.

Schmitt, C. (1985) Political Theology: Four Chapters on the Concept of Sovereignty trans. by George Schwab, MIT Press, Cambridge, MA.

Schmitt, C. (1991) Glossarium: Aufzeichnungen aus den Jahren 1957-51 ed.

Eberhard Freiherr von Medem, Duncker \& Humblot, Berlin.

Schmitt, C. (2008) The Leviathan in the State Theory of Thomas Hobbes: Meaning and Failure of a Political Symbol trans. by George Schwab and Erna Hilfstein University of Chicago Press, Chicago, IL.

Schuhl, P.M. (1947) Machinisme et philosophie, PUF, Paris.

Shapin S. and Shaffer, S. (1985) Leviathan and the Air Pump: Hobbes, Boyle and the Experimental Life, Princeton University Press, Princeton, NJ.

Smith, A. (2015) The Political Machine: Assembling Sovereignty in the Bronze Age Caucasus (The Rostovtzeff Lectures), Princeton University Press, Princeton, NJ.

Stiegler B. (2016) Automatic Society: Volume 1: The Future of Work, Polity, London. De Vries, H. and Weber, S. (2002) Religion and Media, Stanford University Press, Stanford, CA.

Weber, S. (2008) Benjamin's-abilities, Harvard University Press, Cambridge, MA. Žižek, S. (2003) The Puppet and the Dwarf: The Perverse Core of Christianity, MIT Press, Cambridge, MA. 
${ }^{1}$ To be sure, Benjamin criticism has already played out every possible variation of the First Thesis to a position of arguably total stalemate. It has variously been read theologically, materially and/or as arguing for some kind of - dialectical, historical or strategic - alliance between theology and materialism. If all these interpretative strategies seem at best half-true, it is arguably because they can do little more than repeat subject positions and variations (reversal, concealment, unmasking, and in every case, the desire to somehow 'win' the game) that are already very well-staked out and undercut by and within, Benjamin's own Thesis. In this sense, we all end up playing the same game against the machine with the same inevitable outcome. See Balfour 1991, Žižek 2003 and Weber 2008 for a range of different readings of the Thesis.

2 See Bradley 2011. In speaking of an 'originary' prosthesis or supplement here, I do not mean to simply reverse the normal hierarchy and attribute prime causality to technology but to call into question the entire relation between the human and the technical.

3 See Rabinbach 1992, De Vries and Weber 2002, Derrida 2009, Esposito 2015, Smith 2015, Stiegler 2016 for work on the relationship between sovereignty, governmentality and technology from a range of disciplinary perspectives. 4 However, the historian of the Ancient World Pierre-Maxime Schuhl (1947) argues that, in reality, the causality flowed in the opposite direction. In Schuhl's view, it is less the case that the absence of advanced of technology in Ancient Greece made slavery necessary, as Aristotle alleges, so much as Ancient Greece's excessive reliance on slave labour was what delayed its technological evolution.

5 If Agamben's own genealogy of slavery in Use of Bodies is typically eclectic, analogical and a-historical (suturing together Aristotle, the Church Fathers, Sade, Marx and Heidegger amongst many others) his basic thesis is that Aristotle's masterslave relation constitutes the forgotten metaphysical origin of the process that culminate in the real subsumption of labour diagnosed by Marx. In Agamben's genealogy, what begins as the master and slave's reciprocal use of each other's bodies in a kind of weak ontological anarchism or communism will - albeit in parodic and reified form - end up with user and tool becoming part of one larger machinic ensemble or production line in the machine stage of capitalism.

6 For me, Agamben's recuperation of Aristotle's theory of natural slavery (despite or because of its left-Heideggerian pathos about a free use of bodies) comes dangerously close to ontologizing masterly violence against the slave - particularly in its normalization of sexual relations between the master and the slave. If Agamben would undoubtedly dismiss such a concern as anachronistic, it is worth recalling that Aristotle himself is explicitly articulating his natural theory of slavery over and against those who already deem it to be unnatural - that it is unjust, for it is based on force' (Aristotle 1984: 1253b). Why would he seek to defend natural slavery in the first place - if it were not already coming under attack?

7 In Descartes' words, 'I might consider the body of a man as a kind of machine equipped with and made up of, bones, nerves, muscles, veins, blood and skin in such a way that, even if there were no mind in it, it would still perform all the same movements as it now does in those cases where movement is not under the control of the will or, consequently, of the mind' (Descartes 1986: 58). 